\title{
Methane flux and high-affinity methanotrophic diversity along the chronosequence of a receding glacier in Greenland
}

\author{
Teresa G. BÁRCENA, ${ }^{1,2}$ Jacob C. YDE, ${ }^{1,2,3}$ Kai W. FINSTER ${ }^{4,5}$ \\ ${ }^{1}$ Center for Geomicrobiology, University of Aarhus, Ny Munkegade 114-116, DK-8000 Aarhus, Denmark \\ E-mail: tgb@geo.au.dk \\ ${ }^{2}$ Department of Earth Sciences, University of Aarhus, Ny Munkegade 120, DK-8000 Aarhus, Denmark \\ ${ }^{3}$ Bjerknes Center for Climate Research, University of Bergen, Allégaten 55, NO-5007 Bergen, Norway \\ ${ }^{4}$ Department of Biological Sciences, University of Aarhus, Ny Munkegade 114, DK-8000 Aarhus, Denmark \\ ${ }^{5}$ Max Planck Institute for Marine Microbiology, Celsiusstrasse 1, D-28359 Bremen, Germany
}

\begin{abstract}
Methane consumption in upland soils represents an important part of the biologically mediated sink of tropospheric methane. The present study focuses on the role of glacier forefields as a potential methane sink. The role of these environments, though increasing in size, has not yet been taken into account in the global methane budget. Net methane fluxes were analysed based on a static chamber method on a proglacial chronosequence from the Mittivakkat valley, southeast Greenland. Methane uptake could be measured in 7 of the $\mathbf{1 2}$ study sites, with highest rates in the oldest materials from the chronosequence, suggesting that methane oxidation potential may increase during glacier recession (80-150 years). In the chamber located at the glacier front, net methane production was observed, indicating that the microbial community changes after glacial recession from being net methanogenic to becoming net methanotrophic. Diversity analyses based on denaturing gradient gel electrophoresis (DGGE) from the methanotrophic communities responsible for methane uptake at atmospheric levels demonstrate that methanotrophic microbial diversity changes along the chronosequence and show that there is a tendency to a larger diversity in the oldest part of the chronosequence. Sequencing of DNA retrieved from the DGGE revealed a restricted diversity of the methanotrophic community: GenBank accession numbers HM534684-HM534736.
\end{abstract}

\section{INTRODUCTION}

During recent decades, efforts have been made to describe global methane budgets accurately in order to understand the dynamics of the sinks and sources of this important greenhouse gas (Adamsen and King, 1993; King, 1997; Berestovskaya and others, 2002, 2005; Mastepanov and others, 2008). Changes in the concentration of atmospheric methane, which is the most abundant organic trace gas in the atmosphere, play an important role in climate change due to its pronounced infrared absorption capacity. Since the industrial revolution the atmospheric $\mathrm{CH}_{4}$ concentration has increased as a consequence of imbalance between the biological and anthropogenic production of methane and its consumption in the environment (Trotsenko and Murrell, 2008). It has been estimated that approximately $30 \mathrm{Tg}$ of atmospheric $\mathrm{CH}_{4}$ per year are oxidized by aerobic methanotrophic bacteria in upland soils, accounting for about $6 \%$ of the global atmospheric $\mathrm{CH}_{4}$ sink (Knief and others, 2003). Since the $\mathrm{CH}_{4}$ cycle is affected by feedback mechanisms from the ongoing global warming (Callaghan and others, 2004; Anisimov, 2007), the scientific community is now focusing on estimating potential climatic feedbacks from rapidly changing environments. An example of such an environment is recently deglaciated glacier forefields, where glacier recession exposes previously subglacial ecosystems to proglacial climatic conditions. As a consequence, changes in microbial community composition and activity may alter net respiration rates and hence affect the consumption or emission of greenhouse gases such as $\mathrm{CO}_{2}, \mathrm{CH}_{4}$ and $\mathrm{N}_{2} \mathrm{O}$. In recent years a growing number of publications have focused on issues concerning glacier forefield ecology (Sigler and Zeyer, 2002; Sigler and others, 2002; Tscherko and others, 2003; Bekku and others, 2004;
Kaštovská and others, 2005; Kandeler and others, 2006; Bardgett and others, 2007; Hämmerli and others, 2007; Nemergut and others, 2007; Yoshitake and others, 2007; Schmidt and others, 2008; Duc and others, 2009; Lazzaro and others, 2009; Strauss and others, 2009). Many of these studies have identified changes in microbial community structures along chronosequence profiles. However, a gap still exists in knowledge about whether glacier recession causes net microbial consumption or emission of $\mathrm{CH}_{4}$ and how significant these changes are to the global $\mathrm{CH}_{4}$ budget. In particular, little attention has been paid to glacier forefields in Greenland, where the recession of glaciers is occurring very fast (Yde and Knudsen, 2007; Mernild and others, 2008). In this paper we present and discuss data on methane fluxes and the underlying methanotrophic microbial community which were obtained during a field campaign to the Mittivakkat valley, Greenland, in August 2009.

\section{STUDY AREA}

The research area is located in the Mittivakkat valley $\left(65^{\circ} 42^{\prime} \mathrm{N}, 31^{\circ} 48^{\prime} \mathrm{W}\right)$, Ammassalik Island, southeast Greenland (Fig. 1). The valley was covered by Mittivakkat Glacier, an outlet glacier descending from a local ice cap, until the end of the Little Ice Age (LIA). It is not known when the glacier started to recede from the LIA moraine, but it was probably between AD 1850 and 1900. It has been documented that since 1933 the glacier terminus has receded approximately $1.3 \mathrm{~km}$ to its current position (Fristrup, 1970; Knudsen and others, 2008). The overall deglaciated valley geomorphology consists of a frontal dump moraine that marks the maximum extent of the LIA and a classic set of 


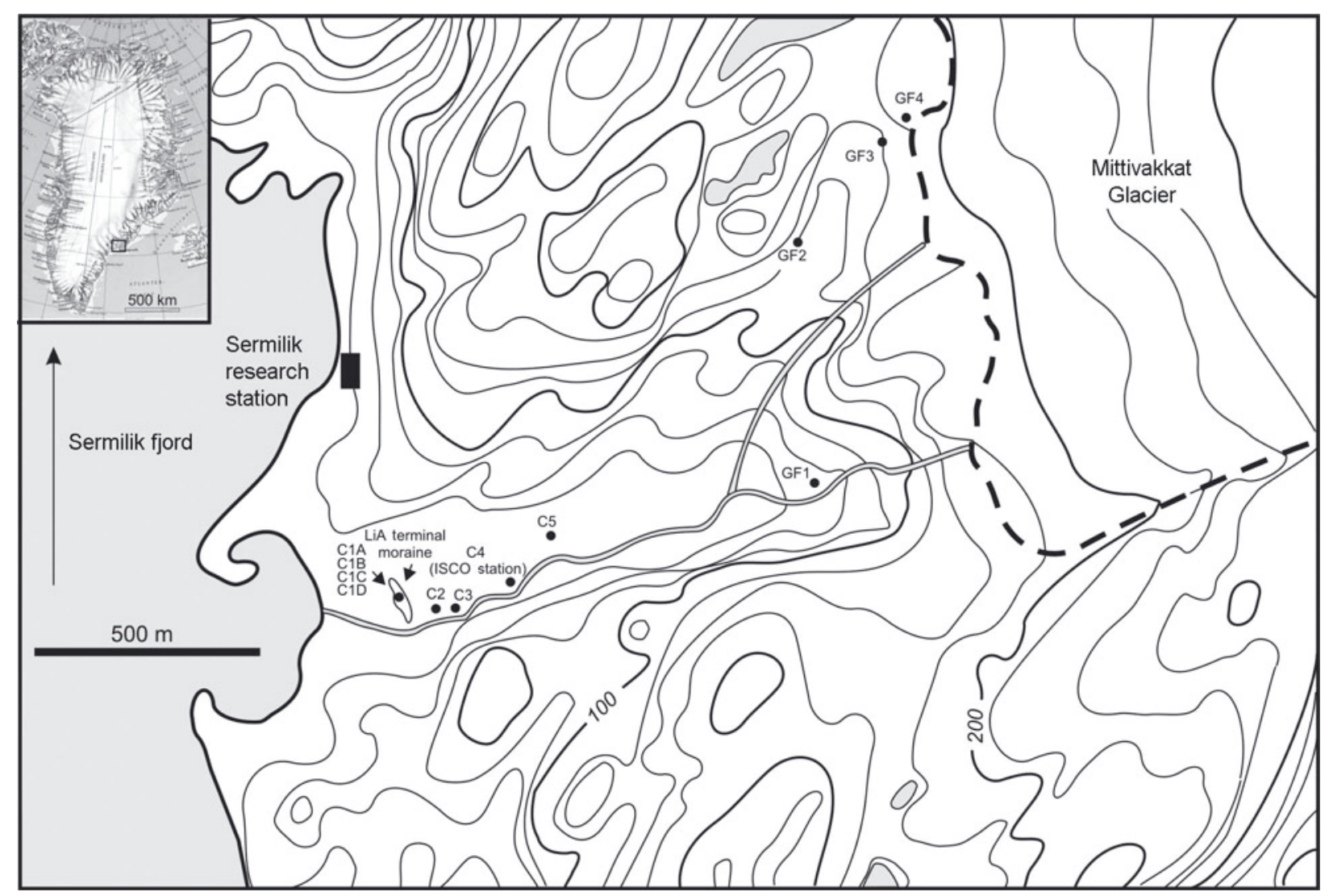

Fig. 1. Location map of the Mittivakkat valley and the proglacial zone with the positions of the flux chamber sites.

successively incised glaciofluvial outwash surfaces, where the highest surface is oldest and the lowest surface is used by the proglacial river today. This clear landform chronology makes the Mittivakkat valley an ideal site for investigating glacier forefield ecology.

The climate is Low Arctic, with a mean annual precipitation of $984 \mathrm{~mm}$ (AD 1961-1990) and a mean annual air temperature (MAAT) of $-1.7^{\circ} \mathrm{C}$ (AD 1961-90), but in the last decade the MAAT has increased to about $0.0^{\circ} \mathrm{C}$ (Cappelen, 2009a). The mean monthly air temperature (AD 1961-90) ranges from $-8.1^{\circ} \mathrm{C}$ in March to $6.4^{\circ} \mathrm{C}$ in July (Cappelen, $2009 \mathrm{~b})$. There is no contemporary permafrost and the LIA moraine is not ice-cored. The vegetation cover is sparse and dominated by a dwarf shrub heath habitat with dwarf birch, greyleaf willow and fell-field communities based on cushion plants (Jakobsen and others, 2008) as well as an abundance of lichens (Hansen, 2010). The geology of Ammassalik Island mainly consists of Archean granite gneiss (Bridgwater, 1976).

\section{METHODS}

In August 2009, a total of 12 sites was studied along a proglacial transect from the LIA moraine to the present glacier terminus (Fig. 1). Sites C1A-C1D were located across the LIA moraine, with $\mathrm{C} 1 \mathrm{~A}$ and $\mathrm{C} 1 \mathrm{~B}$ on the distal side, $\mathrm{C} 1 \mathrm{C}$ on the top and C1D on the proximal side; sites C2-C4 were situated on glaciofluvial outwash surfaces inside the LIA moraine, where C2 was oldest and C4 was youngest; site C5 was located on a small moraine ridge that was younger than C4 and deposited some years before 1933 (Fristrup, 1970); site GF1 was on top of a moraine ridge, which was deglaciated a few years after 1958 (Fristrup, 1970); site
GF2 was situated on glaciofluvial sediments within a tributary valley and was exposed in the 1980s; site GF3 consisted of glaciofluvial sediments and was deglaciated during the summer of 2004; and site GF4 was located about $1 \mathrm{~m}$ from the glacier terminus in August 2009 and had been deglaciated within the previous year. The reason for the intensive sampling of the LIA moraine was that we expected differences in microclimatic environments, microscale slope processes and soil development on the distal side, top and proximal side, respectively.

\section{Methane flux analysis}

Methane fluxes were determined by the static chamber technique (Priemé and Christensen, 1997; Smith and others, 2002; Berestovskaya and others, 2005) combined with flame ionization gas chromatography. The chambers were $25 \mathrm{~cm}$ long polyvinylchloride cylinders with an internal diameter of $9.4 \mathrm{~cm}$, which were inserted $10 \mathrm{~cm}$ into the sediment to give a final headspace volume of $\sim 1 \mathrm{~L}$. The chambers were left open to the atmosphere for approximately 1 day before the beginning of the experiment. Samples of air at the same level where the chambers were placed were collected before the beginning of the experiment to determine initial methane atmospheric concentrations at each site. Sampling ports ( $9 \mathrm{~mm}$ diameter) on every chamber were then sealed with a rubber stopper to ensure gas-tight conditions throughout the experiment. Gas samples were withdrawn with a syringe from the headspace of the chambers and stored in $5 \mathrm{~mL}$ evacuated Exetainer vials (Labco Ltd, Buckinghamshire, UK) containing $1 \mathrm{~mL}$ of $1 \mathrm{M} \mathrm{NaOH}$. Gas samples were taken at 24 hour intervals during a period of up to 5 days. Three gas samples at each time of analysis were taken for the four chambers on the LIA terminal moraine ridge $(\mathrm{C} 1 \mathrm{~A}, \mathrm{C} 1 \mathrm{~B}$, 
C1C and C1D), while two gas samples were taken for the rest of the chambers in the chronosequence. After sampling gas from the headspace of the chambers, the withdrawn volume was compensated with the same volume in atmospheric air to maintain pressure conditions within the chamber. Analysed methane concentrations were corrected for this addition of methane. Analysis of the $\mathrm{CH}_{4}$ was performed by gas chromatography on an SRI 310C GC (SRI, Torrance, CA, USA) with a $3 \mathrm{ft} \times 1 / 8$ in $(\sim 0.91 \mathrm{~m} \times 3.18 \mathrm{~mm})$ silica-gel packed column (column i.d. 8600-PK1A) using helium as the carrier gas. Oven temperature was $40^{\circ} \mathrm{C}$ and the temperature in the field ionization detector was $155^{\circ} \mathrm{C}$. Gas samples $(500 \mu \mathrm{L})$ were injected into the GC system and analysed by simultaneous integration of the peaks in the chromatograph with the Peak Simple 2000 software (SRI, Torrance, CA, USA). Based on this set-up it was possible to reliably detect $\mathrm{CH}_{4}$ concentrations down to $0.2 \mathrm{ppm}$. Standards were run in the system before and after the measurements to verify their quality and perform calibration.

The oxidation rate of atmospheric methane was estimated from first-order decreases in headspace methane concentrations based on:

$$
\text { Rate }=C_{0} \times \mathrm{e}^{-k t},
$$

where $C_{0}$ is initial $\mathrm{CH}_{4}$ concentration, $k$ is a first-order rate constant for $\mathrm{CH}_{4}$ consumption at approximately atmospheric concentrations (Ishizuka and others, 2009) and $t$ is time. We followed changes in methane concentrations for a time period of 72 hours, because we were confident that the measurements based on this time interval could not arise from analytical artefacts.

\section{pH}

The $\mathrm{pH}$ analysis was performed in distilled water and $1 \mathrm{M}$ $\mathrm{KCl}$ (two subsamples from each site) with a pHM 64 Research pH meter (Radiometer, Copenhagen, Denmark) to determine the actual and potential acidity of the soil sample, respectively. $10 \mathrm{~g}$ of sediment sample and $10 \mathrm{~g}$ of fluid (distilled water or $\mathrm{KCl}$ ) were weighed into $20 \mathrm{~mL}$ plastic beakers and stirred four times during $30 \mathrm{~min}$, and left afterwards for $30 \mathrm{~min}$ without stirring. The glass electrode was adjusted in buffer solutions and set to the temperature of the fluid before it was lowered into the sample to conduct the measurement (Nørnberg and Dalsgaard, 2005).

\section{Molecular analysis based on $p m o A$ genes}

\section{Soil DNA extraction}

Sediment subsamples (approximately $0.5 \mathrm{~g}$ ) from each study site were used for DNA extraction and purification with the Fast DNA Spin Kit for Soil according to the manufacturer's instructions (Bio101, La Jolla, CA, USA).

\section{Genetic fingerprinting: denaturing gradient gel electrophoresis}

In order to assess the presence of methanotrophs, a prior analysis based on polymerase chain reaction (PCR) was performed, using the primer set A189F-A650R targeting the pmoA functional gene sequence (Bourne and others, 2001). This primer set encodes one of the subunits of the particulate methane monooxygenase (pMMO), an enzyme found universally in most methanotrophs (for exceptions see Dedysh and others, 2000). After ensuring that the PCR product had the correct size, a GC clamp was added to the forward primer (GC-A189F) for further analysis with denaturing gradient gel electrophoresis (DGGE). The analysis was based on two equal gels $(0.75 \mathrm{~mm} \times 16 \mathrm{~mm} \times 16 \mathrm{~mm})$ of $8 \% \mathrm{w} / \mathrm{v}$ acrylamide in a denaturant gradient from $30 \%$ to $70 \%$. The low denaturant was based on a mixture of $20 \% \mathrm{w} / \mathrm{v}$ urea and formamide in $8 \% \mathrm{w} / \mathrm{v}$ acrylamide, while a mixture of $80 \% \mathrm{w} / \mathrm{v}$ urea and formamide in $8 \% \mathrm{w} / \mathrm{v}$ acrylamide was used for the high denaturant. The same PCR products were loaded on both gels, with slight differences in loaded volume on each gel (gel 2 had 1 or $2 \mu \mathrm{L}$ higher load of PCR product compared with gel 1). The gels were run in $1 \times \mathrm{TAE}$ buffer (40 mM Tris- $\mathrm{HCl}, 20 \mathrm{mM}$ acetic acid, 1 mM EDTA, pH 8.3) at $60^{\circ} \mathrm{C}$ and $100 \mathrm{~V}$ for 15 hours using the DCode Universal Mutation Detection System electrophoresis apparatus (BioRad, Hercules, CA, USA) connected to a PowerPac 300 power supply (BioRad, Hercules, CA, USA). The gels were stained in a bath containing $200 \mathrm{~mL}$ of $1 \times$ TAE buffer and $10 \mu \mathrm{L}$ of DNA staining dye Sybr Gold (Invitrogen, Carlsbad, CA, USA) for $60 \mathrm{~min}$. Finally, results were visualized with UV translumination on the GelDoc 2000 system (BioRad, Hercules, CA, USA) and photographed for further analysis.

Bands from both DGGE gels were excised for further analysis based on sequencing. The sequencing was conducted by the commercial company Macrogen (Korea).

\section{Band analysis of the DGGE images}

Band patterns from both gels were analysed and processed with the Gel Doc 2000 gel documentation system and the Quantity One (version 4.2.1) software (BioRad, Hercules, CA, USA) based on peak densities (i.e. the intensity value of a band's peak) of each band as a main parameter to compare between lanes and bands. Band analysis was performed with precisely the same settings (sensitivity, noise filter, minimum density, etc.) and background substraction (based on the rolling disk method) on both gels to compare the band retrieval depending on the differences in sample load between gels. Sensitivity (i.e. the minimum signal intensity defined as a band) was determined with an absolute value of four, to avoid erroneous detection of bands. We produced two identical gels with different loads to ensure consistent sequencing results and to determine the effect of different volumes on the band patterns.

In addition, DGGE profiles were analysed for diversity based on the Shannon index $\left(H^{\prime}\right)$ according to:

$$
H^{\prime}=-\sum\left(n_{i} / N\right) \ln \left(n_{i} / N\right)
$$

where $n_{i}$ corresponds to the peak density of each detected band and $N$ represents the total peak density of all bands in one lane, giving the theoretical proportional abundance of different $p m o A$ sequences within the different lanes (Sigler and Zeyer, 2002; Trevors and others, 2010).

\section{DGGE band sequence analysis}

The sequences that were retrieved successfully from the DGGE bands were analysed using the NCBI BLAST tool with the NCBI nt database as reference (Altschul and others, 1997). They were grouped according to their affiliation to sequences in the database.

\section{RESULTS}

\section{Methane flux}

In situ net methane oxidation rates were detected in 7 of the 12 chambers and ranged between 0.14 and 


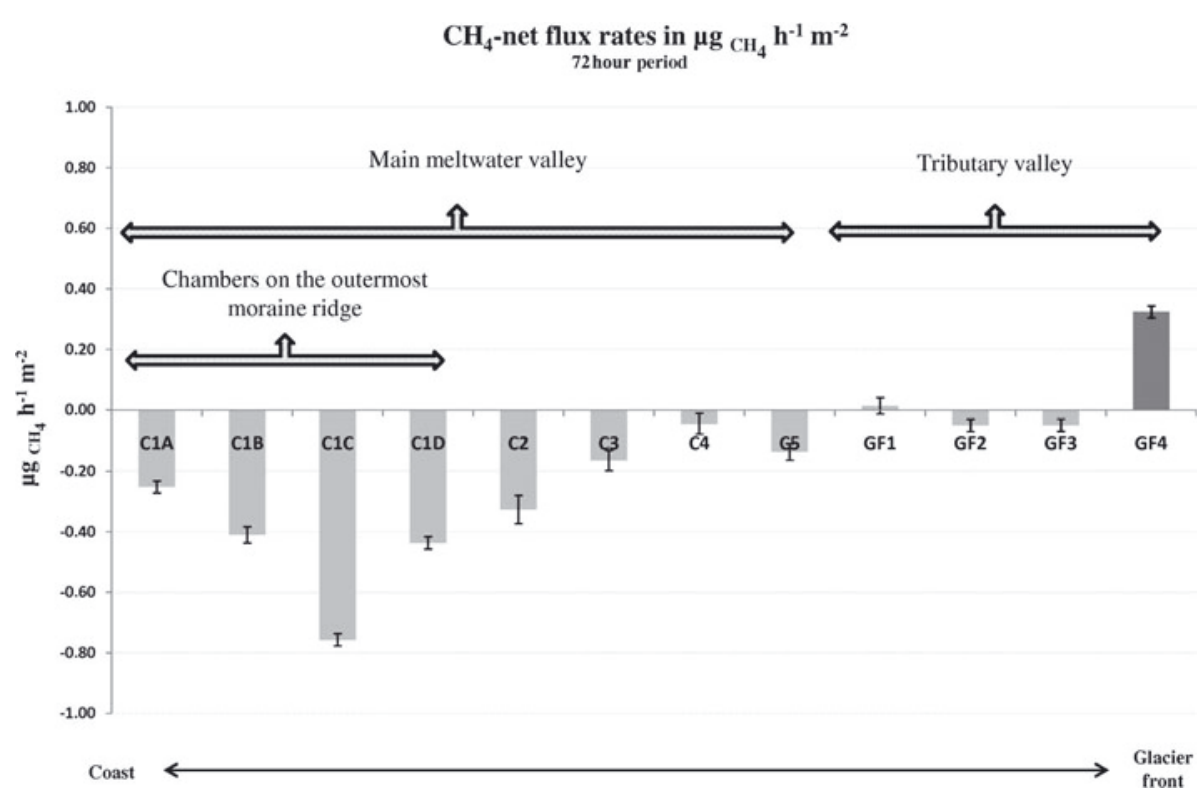

Fig. 2. Net flux rates calculated from headspace methane concentrations in the flux chambers over time, along the Mittivakkat valley chronosequence. Negative values represent net methane consumption and positive values represent net methane production.

$0.76 \mu \mathrm{g}_{\mathrm{CH} 4} \mathrm{~h}^{-1} \mathrm{~m}^{-2} \pm 0.02-0.05 \mu \mathrm{g}_{\mathrm{CH} 4} \mathrm{~h}^{-1} \mathrm{~m}^{-2}$ (Fig. 2). Four chambers did not show significant changes in $\mathrm{CH}_{4}$ headspace concentrations over the course of the experiment (C4, GF1, GF2 and GF3). An efflux of $\mathrm{CH}_{4}$ (net $\mathrm{CH}_{4}$ production) was observed in the chamber located $\sim 1 \mathrm{~m}$ from the glacier front (GF4). This site represents a deglaciation that took place between the summers of 2008 and 2009.

The highest $\mathrm{CH}_{4}$ oxidation rate was determined on top of the LIA moraine ridge (site $\mathrm{C} 1 \mathrm{C}$ ) and reached $0.76 \mu \mathrm{g}_{\mathrm{CH} 4} \mathrm{~h}^{-1} \mathrm{~m}^{-2}$. The variability in the rates of $\mathrm{CH}_{4}$ oxidation across the LIA moraine (sites C1A-C1D) showed that the $\mathrm{CH}_{4}$ oxidation rate increased towards the top of the moraine ridge. The reasons for this have yet to be determined, but it is likely that the stage of soil development and stability are important controls. As a general pattern, it was observed that the $\mathrm{CH}_{4}$ oxidation potential tends to decrease along the chronosequence towards the glacier front.

\section{pH}

The $\mathrm{pH}$ values indicate an acidic environment varying in the range 3.9-4.6 in 11 of the 12 sampling sites, based on values obtained from $1 \mathrm{M} \mathrm{KCl}$ (Table 1). A relatively higher $\mathrm{pH}$ value (6.3) was found near the glacier terminus at site GF4. Unpublished $\mathrm{pH}$ measurements in glacier meltwater at Mittivakkat Glacier showed values between 6.4 and 7.3 in August (data not shown). This indicates that glacial meltwater most likely infiltrates the near-marginal glaciofluvial sediments at site GF4.

\section{Methanotrophic diversity}

The DGGE patterns indicate a shift in diversity of $p m o A$ gene sequences along the chronosequence. Subsamples obtained from top soil of the LIA terminal moraine ridge presented almost identical diversity patterns (Fig. 3a and b), demonstrating the homogeneous distribution of the methanotrophic microbial community within the same geomorphological unit. However, the patterns observed along the entire chronosequence changed gradually towards the youngest part.

No pmoA genes could be retrieved from sites GF2 and GF4; therefore, these samples were not included in the DGGE analysis.

Based on the number of bands detected on the DGGE images, samples from sites $\mathrm{C} 1 \mathrm{~B}$ and $\mathrm{C} 4$ contained the highest diversity of all studied sites. These patterns were consistent, since they were retrieved on both gels. In general, the Shannon index of diversity increased in the second gel (Table 2), where the volume of sample was larger and more bands in almost all lanes were detected.

A comparison of the 55 out of 56 sequences that could be retrieved successfully from the DGGE bands with sequences stored in the $\mathrm{NCBI}$ nt database confirmed that all sequences were $p m o A$ gene sequences. With the exception of a single sequence all sequences were closely affiliated with sequences that we recently obtained by cloning and sequencing from soil samples collected at the LIA moraine site and C5 in summer 2008. Of the 54 sequences, 28 fell into

Table 1. $\mathrm{pH}$ values in the top soil at the sampling sites along the Mittivakkat valley chronosequence

\begin{tabular}{|c|c|c|c|c|c|c|c|c|c|c|c|c|}
\hline & \multicolumn{12}{|c|}{ Chamber } \\
\hline & C1A & C1B & C1C & C1D & $\mathrm{C} 2$ & $\mathrm{C} 3$ & $\mathrm{C} 4$ & C5 & GF1 & GF2 & GF3 & GF4 \\
\hline $\mathrm{pH}\left(\mathrm{dH}_{2} \mathrm{O}\right)$ & 5.95 & 6.12 & 6.33 & 6.23 & 5.75 & 5.84 & 5.9 & 6.07 & 6.2 & 4.5 & 4.85 & 6.95 \\
\hline $\mathrm{pH}(\mathrm{KCl})$ & 4.24 & 4.41 & 4.53 & 4.49 & 4.27 & 4.29 & 4.46 & 4.56 & 4.64 & 3.94 & 4.19 & 6.27 \\
\hline
\end{tabular}


a

\section{ฮ}

$1.21 \Delta$

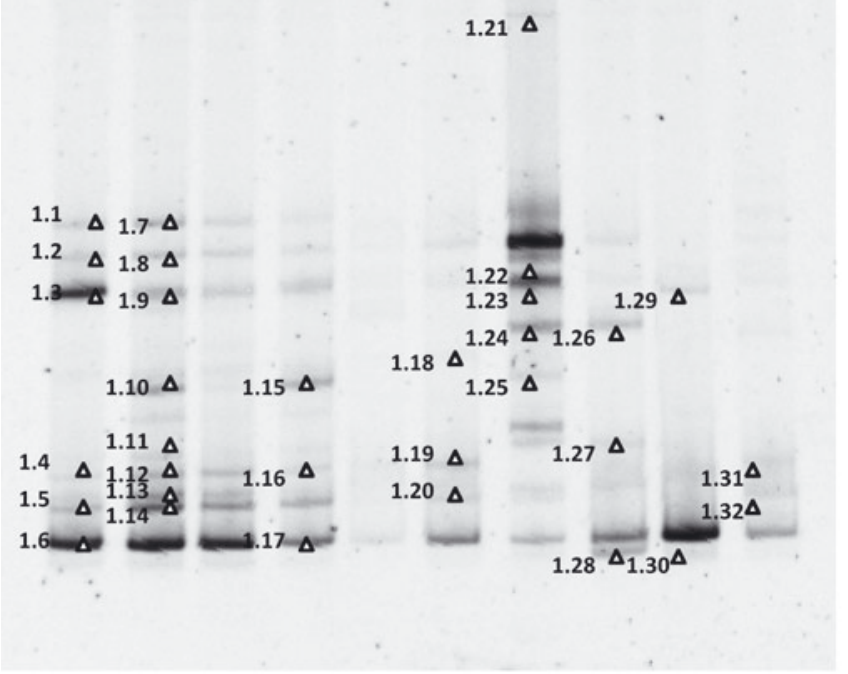

b

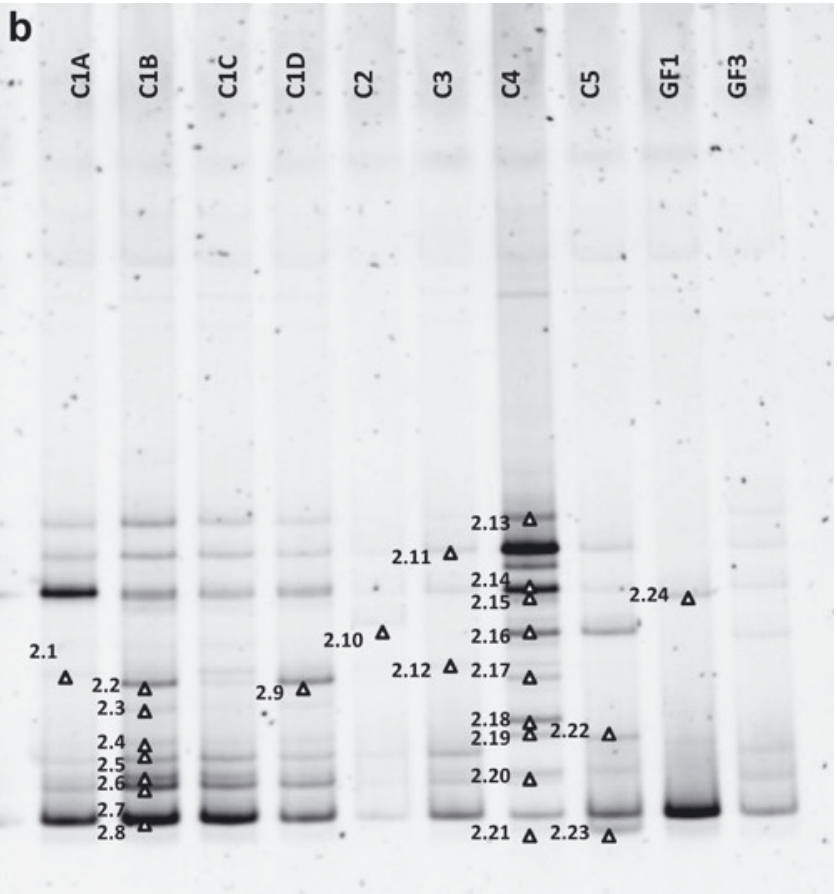

Fig. 3. DGGE images of the Mittivakkat valley chronosequence. Numbers shown on the gels correspond to the band indicated by the triangle, which was extracted for further analysis (sequencing). Band numbers 1.1-1.32 (total of 32 bands) and 2.1-2.24 (total of 24 bands) refer to (a) the first and (b) the second gel. The amount of sample loaded in the gel shown in (a) ranged from 7 to $11 \mu \mathrm{L}$ depending on the strength of the PCR product, while the gel in (b) contained 1-2 $\mu \mathrm{L}$ extra sample load. Both gels have the same $30-70 \%$ denaturant gradient.

cluster 4, 19 into cluster 3, 6 into cluster 2, and 1 into cluster 1 (Table 3). These clusters fell into a group of high-affinity methanotrophs within the $\alpha$-subdivision of Proteobacteria.

The applied methods demonstrate that the amount of PCR product loaded on the DGGE gel positively affected the number and the intensity of single bands in the gel upon staining, enhancing the importance of considering this factor relevant for the achievement of a comprehensive DGGE result.

\section{DISCUSSION}

\section{Methane flux}

Methane uptake rates in soils vary in a relatively wide range depending on ecosystem characteristics (King, 1997; Smith and others, 2002). A study from Knief and others (2003) shows that methanotrophic upland soil communities (i.e. well drained and oxic) are able to consume methane at atmospheric concentrations. They argue that aerobic methanotrophic communities inhabiting these environments present high affinity for methane and should therefore be considered as highly specialized oligotrophs. In this study we are able to show that communities with equivalent properties inhabit a deglaciated forefield in southeast
Greenland. Like the upland soil community studied by Knief and others (2003), the glacier forefield community consumes methane at atmospheric levels. This is, to our knowledge, the first report of in situ $\mathrm{CH}_{4}$ flux measurements in this habitat type.

Methane flux studies based on flux chambers may present some methodic limitations. During an experiment, $\mathrm{CH}_{4}$ depletion in the headspace of the chamber may cause a reduction in methanotrophic activity compared with the surrounding soil that is exposed to ambient $\mathrm{CH}_{4}$, and lateral $\mathrm{CH}_{4}$ diffusion could supplement the soil methane supply (von Fischer and others, 2009). Also, increased temperature or moisture inside the chamber may affect the observed methanotrophic potential. Despite these limitations of the experimental set-up, we are convinced that the observed trends are real and reflect the situation in situ. However, more detailed studies need to be conducted in the future to evaluate the quality of the results.

Consumption rates at the Mittivakkat Glacier forefield are low compared with those measured in forest soils (Ishizuka and others, 2009; Jang and others, 2009), tundra environments (Whalen and Reeburgh, 1990) or landfill areas (Hanson and Hanson, 1996) and lie at the low end of rates reported so far (Table 4).

Table 2. Values for the Shannon diversity index $\left(H^{\prime}\right)$ in both gels

\begin{tabular}{|c|c|c|c|c|c|c|c|c|c|c|}
\hline & \multicolumn{10}{|c|}{ Chamber } \\
\hline & $\mathrm{C} 1 \mathrm{~A}$ & C1B & C1C & C1D & $\mathrm{C} 2$ & C3 & $\mathrm{C} 4$ & C5 & GF1 & GF3 \\
\hline Gel 1 & 1.61 & 2.50 & 1.77 & 1.76 & 0.12 & 0.90 & 2.20 & 1.13 & 0.45 & 0.66 \\
\hline Gel 2 & 1.54 & 2.72 & 1.93 & 1.73 & 0.37 & 0.97 & 2.95 & 1.38 & 0.53 & 0.84 \\
\hline
\end{tabular}


Table 3. Affiliation of sequences retrieved from DGGE bands with sequences stored in the GenBank database. All sequences affiliated with sequences of high-affinity type II methanotrophs within the $\alpha$ subdivision of Proteobacteria

\begin{tabular}{|c|c|c|c|}
\hline Sample site & $\begin{array}{l}\text { DGGE band } \\
\text { number }\end{array}$ & $\begin{array}{c}\text { Blast hits } \\
\text { (accession number) }\end{array}$ & $\begin{array}{l}\text { Cluster in } \\
\text { library }\end{array}$ \\
\hline \multirow[t]{7}{*}{ C1A } & 1.1 & FN651647 & III \\
\hline & 1.2 & FN651657 & II \\
\hline & 1.3 & FN651657 & II \\
\hline & 1.4 & FN651656 & IV \\
\hline & 1.5 & FN651656 & IV \\
\hline & 1.6 & FN651643 & IV \\
\hline & 2.1 & FN651656 & IV \\
\hline \multirow[t]{15}{*}{ C1B } & 1.7 & FN651648 & III \\
\hline & 1.8 & FN651648 & III \\
\hline & 1.9 & FN651657 & II \\
\hline & 1.1 & FN651657 & II \\
\hline & 1.11 & FN651656 & IV \\
\hline & 1.12 & FN651656 & IV \\
\hline & 1.13 & FN651656 & IV \\
\hline & 1.14 & FN651656 & IV \\
\hline & 2.2 & FN651657 & II \\
\hline & 2.3 & FN651656 & IV \\
\hline & 2.4 & FN651656 & IV \\
\hline & 2.5 & FN651656 & IV \\
\hline & 2.6 & FN651656 & IV \\
\hline & 2.7 & FN651655 & III \\
\hline & 2.8 & FN651656 & IV \\
\hline \multicolumn{4}{|l|}{ C1C } \\
\hline \multirow[t]{4}{*}{ C1D } & 1.15 & FN651815 & IV \\
\hline & 1.16 & FN651656 & IV \\
\hline & 1.17 & FN651656 & IV \\
\hline & 2.9 & FN651657 & II \\
\hline C2 & 2.1 & FN651648 & III \\
\hline \multirow[t]{5}{*}{$\mathrm{C} 3$} & 1.18 & FN651648 & III \\
\hline & 1.19 & FN651656 & IV \\
\hline & 1.2 & FN651656 & IV \\
\hline & 2.11 & FN651648 & III \\
\hline & 2.12 & FN651658 & I \\
\hline \multirow[t]{14}{*}{ C4 } & 1.21 & FN651648 & III \\
\hline & 1.22 & FN651648 & III \\
\hline & 1.23 & FN651655 & III \\
\hline & 1.24 & FN651648 & III \\
\hline & 1.25 & FN651816 & IV \\
\hline & 2.13 & FN651648 & III \\
\hline & 2.14 & FN651648 & III \\
\hline & 2.15 & FN651648 & III \\
\hline & 2.16 & FN651648 & III \\
\hline & 2.17 & FN651656 & IV \\
\hline & 2.18 & FN651815 & IV \\
\hline & 2.19 & FN651644 & IV \\
\hline & 2.2 & FN651815 & IV \\
\hline & 2.21 & FN651656 & IV \\
\hline \multirow[t]{5}{*}{ C5 } & 1.26 & FN651648 & III \\
\hline & 1.27 & Poor sequence & \\
\hline & 1.28 & FN651648 & III \\
\hline & 2.22 & FN651656 & IV \\
\hline & 2.23 & FJ970555 & \\
\hline \multirow[t]{3}{*}{ GF1 } & 1.29 & FN651648 & III \\
\hline & 1.3 & FN651815 & IV \\
\hline & 2.24 & FN651648 & III \\
\hline \multirow[t]{2}{*}{ GF3 } & 1.31 & FN651656 & IV \\
\hline & 1.32 & FN651656 & IV \\
\hline
\end{tabular}

The data presented in this study demonstrate that glacier forefields constitute potential sinks of $\mathrm{CH}_{4}$ during late stages after glacial recession (after 80-150 years of exposure). Even though the potential of these areas as a methane sink is modest, resembling the capacity of, for instance, arable soil (Dobbie and others, 1996) to oxidize $\mathrm{CH}_{4}$, it is necessary to take them into account as part of the $\mathrm{CH}_{4}$ sink budget in upland soils. The need to include this type of environment is also supported by the fact that areas representing deglaciated forefields are increasing in size worldwide as a result of enhanced glacier recession.

Besides methanotrophy, methanogenesis is a relevant process in glacier forefields. Based on the presented net flux data, net $\mathrm{CH}_{4}$ production and release to the atmosphere was observed in the chamber located immediately in front of the glacier terminus (GF4). This observation of methanogenesis in recently exposed material is in accordance with findings reported by Wadham and others (2008), who presented evidence for subglacial methanogenesis.

We suggest that the observed shift in net flux $\mathrm{CH}_{4}$ from being methane-releasing at the glacier front to becoming methane-consuming in the older parts of the chronosequence is most likely a result of a changing availability of oxygen. The recently exposed sediments at the glacier front are most likely anoxic and thus support methanogenic Archaea, whereas the older sediments in the forefield area are well oxygenated and thus support a methanotrophic microbial community. Archaeal clone libraries from soil collected at site $\mathrm{C} 1 \mathrm{~A}$ (outermost terminal moraine) and the glacial front location GF4 support this argument (data not shown). While the GF4 Archaea community was dominated by methanogen-related $16 \mathrm{~S}$ rDNA clones, the C1A library was free of methanogen-related $16 \mathrm{~S}$ rDNA clones but contained a diverse archaeal community.

The $\mathrm{pH}$ at the different sampling locations deserves special consideration because it is an important environmental factor that has a strong influence on the distribution and activity of methanotrophs and methanogens across the forefield. Since the Mittivakkat Glacier forefield is only poorly buffered, shifts in $\mathrm{pH}$ are likely to take place and $\mathrm{pH}$ might therefore have had a significant influence on the shaping of the methanotrophic soil community during glacier recession since the LIA. Hitherto, only view reports on methanotrophs from acidic Arctic environments have been published (Dedysh and others, 2000). Thus, our report adds to the sparse number of observations on the activity and diversity of methanotrophs in this habitat type. We hope to follow up on this issue with additional studies in the near future.

Overall, we hypothesize that as redox conditions, access to oxygen and $\mathrm{pH}$ change, the microbial communities involved in $\mathrm{CH}_{4}$ cycling are changing accordingly as long as types that are able to meet the environmental constraints of the specific systems are present within the pool of methanotrophic bacterial strains. The interactions between the environmental conditions and the responsive microbial community are ultimately reflected in the net methane fluxes.

\section{Methanotrophic diversity}

A successful retrieval of pmoA gene sequences in all samples from the chronosequence, with the exception of two (GF2 and GF4), was achieved. However, the detection of a particular $p m o A$ gene in a soil does not necessarily imply that the respective methanotroph is physiologically active in the soil (Knief and others, 2003). In a previous study we observed differences between activity and presence of methane oxidizers in samples from the Mittivakkat Glacier forefield (unpublished information). In this study, we 
Table 4. Rates of atmospheric methane consumption measured in different low-rate environments, based on flux chamber experiments

\begin{tabular}{|c|c|c|}
\hline Location & Source & $\begin{array}{c}\text { Rate } \\
\mu \mathrm{g} \mathrm{CH}_{4} \mathrm{~m}^{-2} \mathrm{~h}^{-1}\end{array}$ \\
\hline $\begin{array}{l}\text { Shortgrass steppe, Colorado, USA } \\
\text { Upland forest soil, New York State, USA } \\
\text { Fertilized grassland, Scotland } \\
\text { Arable land, Kongelunden, Denmark } \\
\text { Forest soil, Sweden } \\
\text { Urban forest, Baltimore, Maryland, USA } \\
\text { Glacier forefield, southeast Greenland }\end{array}$ & $\begin{array}{l}\text { Mosier and others (1991) } \\
\text { Yavitt and others (1993) } \\
\text { Dobbie and others (1996) } \\
\text { Smith and others (2002) } \\
\text { Groffman and Pouyat (2009) } \\
\text { This study }\end{array}$ & $\begin{array}{c}4.2-62.5 \\
15.8-33.3 \\
0.4-19.2 \\
2.9-5.0 \\
0.42-18.75 \\
9.6 \\
0.14-0.76\end{array}$ \\
\hline
\end{tabular}

successfully retrieved $p m o A$ genes from two of the samples where no activity could be detected previously (C4 and GF1), indicating that discrepancies exist between measurable activity and detectable presence. This may be due to the amplification of genetic material by PCR, which may render even small populations visible, the activity of which may not be observable due to the detection limits from the GC method.

With the purpose of performing diversity analyses, individual PCR products from all studied sites were separated by DGGE resulting in different band patterns, of which each band was theoretically representing a predominant member in the targeted microbial community, in this case high-affinity methanotrophs. Limitations of different molecular techniques such as DGGE have been described previously (Muyzer and Smalla, 1998). In the case of DGGE analysis, it has been demonstrated that it is not always possible to separate DNA fragments with a certain sequence variation, which has been the case for DGGE diversity studies on methanotrophic bacteria based on 16S rDNA fragments (Vallaeys and others, 1996). However, in this study we focus on the functional gene pmoA. In a previous diversity study, some difficulties were encountered when extraction and sequencing of the extracted DGGE bands were performed, probably due to a poor separation between DGGE bands. Cloning was therefore required. In the present study, a successful band separation in the gel made it possible to excise and sequence the obtained bands and thereby obtain pmoA gene sequences and compare them with previous results. Interestingly, all retrieved sequences fell into the clusters described in a previous study (unpublished information) and which affiliate with high-affinity type II methanotrophs. As was also the case when clone libraries were investigated, the majority of DGGE band sequences were closely affiliated with cluster 4 sequences. These independent observations confirm that the dominant methanotroph type in the deglaciated Mittivakkat valley belongs to a community of methanotrophs with a restricted diversity. A restricted diversity is also reported by Liebner and others (2009) in a study of methanotrophic community composition in Arctic permafrost. The authors explain the limited diversity by the fact that these organisms have to cope with a combination of environmental extremes that only a limited number of methanotrophs can respond to. This argument may also be applicable when explaining the restricted diversity in the Mittivakkat Glacier forefield. In addition, restricted diversity was also reported from other extreme environments such as peat bogs and acidic forest soil (McDonald and others,
1996; McDonald and Murrell, 1997; Radajewski and others, 2002)

Our observation of the exclusive presence of high-affinity type II methanotrophs is in contrast to reports of methanotrophic diversity in Northern Hemisphere permafrost methanotroph communities (Liebner and Wagner, 2007; Liebner and others, 2009; Martineau and others, 2010). These studies report on the dominant retrieval of low-affinity type I methanotrophs in the investigated permafrost soil. This difference in community composition is most likely due to the fact that the methane concentrations in the active layer of the permafrost soil are much higher as a result of indigenous methane production compared with the forefield sediments that we investigated and that glacier forefields receive methane exclusively from the atmosphere. A similar dominance of type II methanotrophs was also reported from other habitats such as different forest and grassland soils that, like the Mittivakkat Glacier forefield, receive methane only at atmospheric concentrations (Ricke and others, 2005; Lau and others, 2007).

\section{CONCLUSION}

Our results demonstrate clearly that recently deglaciated areas ultimately may act as a net sink for atmospheric $\mathrm{CH}_{4}$. We recommend further studies of the proglacial zone of receding glaciers to address more accurately the dynamics of net $\mathrm{CH}_{4}$ fluxes in these highly dynamic environments.

In addition, sites like the Mittivakkat valley are excellent environments in which to study the in situ colonization by pioneer microbial communities and to study the community shift upon transition from anoxic methanogenic subglacial conditions to oxic methanotrophic proglacial conditions. Overall, the Mittivakkat Glacier forefield represents an excellent natural laboratory in which the important consequences of climate-induced glacier retreat can be followed in situ.

\section{ACKNOWLEDGEMENTS}

This research was funded by the Commission for Scientific Research in Greenland (KVUG - project No. 495229), Carlsbergfondet and the Faculty of Science, University of Aarhus. We thank N.T. Knudsen, T. Wiegers, S.M. Kristiansen and E.N. Bak for field assistance and S. Flury for inspiring discussions. T. Wiegers is also acknowledged for her valuable assistance with molecular analyses and fieldwork. R. Nielsen is acknowledged for map design. We also thank B. Eriksen, B. Rasmussen and M. Sloth for their contribution with $\mathrm{pH}$ 
analyses. We are grateful to the Department of Geography and Geology (IGG), University of Copenhagen, for allowing us to use the Sermilik Research Station. This is publication No. A309 from the Bjerknes Centre for Climate Research.

\section{REFERENCES}

Adamsen, A.P.S. and G.M. King. 1993. Methane consumption in temperate and subarctic forest soils: rates, vertical zonation, and responses to water and nitrogen. Appl. Environ. Microbiol., 59(2), 485-490.

Altschul, S.F. and 6 others. 1997. Gapped BLAST and PSI-BLAST: a new generation of protein database search programs. Nucleic Acids Res., 25(17), 3389-3402.

Anisimov, O. 2007. Potential feedback of thawing permafrost to the global climate system through methane emission. Environ. Res. Lett., 2(4), 045016. (10.1088/1748-9326/2/4/045016.)

Bardgett, R.D. and 10 others. 2007. Heterotrophic microbial communities use ancient carbon following glacial retreat. Biol. Lett., 3(5), 487-490.

Bekku, Y.S., T. Nakatsubo, A. Kume and H. Koizumi. 2004. Soil microbial biomass, respiration rate, and temperature dependence on a successional glacier foreland in $\mathrm{Ny}$-Ålesund, Svalbard. Arct. Antarct. Alp. Res., 36(4), 395-399.

Berestovskaya, Yu.Yu., L.V. Vasil'eva, O.V. Chestnykh and G.A. Zavarzin. 2002. Methanotrophs of the psychrophilic microbial community of the Russian arctic tundra. Microbiology, 71(4), 460-466.

Berestovskaya, Yu.Yu., I.I. Rusanov, L.V. Vasil'eva and N.V. Pimenov. 2005. The processes of methane production and oxidation in the soils of the Russian Arctic tundra. Microbiology, 74(2), 221-229.

Bourne, D.G., I.R. McDonald and J.C. Murrell. 2001. Comparison of pmoA PCR primer sets as tools for investigating methanotroph diversity in three Danish soils. Appl. Environ. Microbiol., 67(9), 3802-3809.

Bridgewater, D. 1976. Nagssugtoqidian mobile belt in East Greenland. In Escher, A. and W.S. Watt, eds. Geology of Greenland. Copenhagen, Geological Survey of Greenland.

Callaghan, T.V. and 13 others. 2004. Effects on the function of Arctic ecosystems in the short- and long-term perspectives. Ambio, 33(7), 448-458.

Cappelen, J. 2009a. DMI daily climate data collection 1873-2008, Denmark, the Faroe Islands and Greenland. Copenhagen, Danish Meteorological Institute. (DMI Tech. Rep. 09-06.)

Cappelen, J. 2009b. DMI monthly climate data collection 1768 2008, Denmark, the Faroe Islands and Greenland. Copenhagen, Danish Meteorological Institute. (DMI Tech. Rep. 09-05.)

Dedysh, S.N. and 8 others. 2000. Methylocella palustris gen. nov., sp. nov., a new methane-oxidizing acidophilic bacterium from peat bogs, representing a novel subtype of serine-pathway methanotrophs. Int. J. Syst. Evol. Microbiol., 50(3), 955-969.

Dobbie, K.E., K.A. Smith, A. Priemé, S. Christensen, A. Degórska and P. Orlanski. 1996. Effect of land use on the rate of methane uptake by surface soils in Northern Europe. Atmos. Environ., 30(7), 1005-1011.

Duc, L., M. Noll, B.E. Meier, H. Bürgmann and J. Zeyer. 2009. High diversity of diazotrophs in the forefield of a receding Alpine glacier. Microbial Ecol., 57(1), 179-190.

Fristrup, B. 1970. Ny geografisk station i Grønland. Geogr. Tidsskr., 69, 192-203.

Groffman, P.M. and R.V. Pouyat. 2009. Methane uptake in urban forests and lawns. Environ. Sci. Technol., 43(14), 5229-5235.

Hämmerli, A., S. Waldhuber, C. Miniaci, J. Zeyer and M. Bunge. 2007. Local expansion and selection of soil bacteria in a glacier forefield. Eur. J. Soil Sci., 58(6), 1437-1445.

Hansen, E.S. 2010. A review of lichen growth and applied lichenometry in southwest and southeast Greenland. Geogr. Ann., Ser. A, 92(1), 65-79.
Hanson, R.S. and T.E. Hanson. 1996. Methanotrophic bacteria. Microbiol. Rev., 60(2), 439-471.

Ishizuka, S. and 11 others. 2009. Methane uptake rates in Japanese forest soils depend on the oxidation ability of topsoil, with a new estimate for global methane uptake in temperate forest. Biogeochemistry, 92(3), 281-295.

Jakobsen, B.H., B. Fredskild and J.B.T. Pedersen. 2008. Holocene changes in climate and vegetation in the Ammassalik area, East Greenland, recorded in late sediments and soil profiles. Geogr. Tidsskr., 108(1), 21-50.

Jang, I., S. Lee, J.-H. Hong and H. Kang. 2009. Methane oxidation rates in forest soils and their controlling variables: a review and a case study in Korea. Ecol. Res., 21(6), 849-854.

Kandeler, E., K. Deiglmayr, D. Tscherko, D. Bru and L. Philippot. 2006. Abundance of narG, nirS, nirk, and nos $Z$ genes of denitrifying bacteria during primary successions of a glacier foreland. Appl. Environ. Microbiol., 72(9), 5957-5962.

Kaštovská, K., J. Elster, M. Stibal and H. Šantréčková. 2005. Microbial assemblages in soil microbial succession after glacial retreat in Svalbard (High Arctic). Microbial Ecol., 50(3), 396-407.

King, G. 1997. Responses of atmospheric methane consumption by soils to global climate change. Global Change Biol., 3(4), 351-362.

Knief, C., A. Lipski and P.F. Dunfield. 2003. Diversity and activity of methanotrophic bacteria in different upland soils. Appl. Environ. Microbiol., 69(11), 6703-6714.

Knudsen, N.T., P. Nønberg, J.C. Yde, B. Hasholt and J. Heinemeier. 2008. Recent marginal changes of the Mittivakkat Glacier, Southeast Greenland and the discovery of remains of reindeer (Rangifer tarandus), polar bear (Ursus maritimus) and peaty material. Geogr. Tidsskr., 108(1), 137-142.

Lau, E., A. Ahmad, P.A. Steudler and C.M. Cavanaugh. 2007 Molecular characterization of methanotrophic communities in forest soils that consume atmospheric methane. FEMS Microbiol. Ecol., 60(3), 490-500.

Lazzaro, A., C. Abegg and J. Zeyer. 2009. Bacterial community structure of glacier forefields on siliceous and calcareous bedrock. Eur. J. Soil Sci., 60(6), 860-870.

Liebner, S. and D. Wagner. 2007. Abundance, distribution and potential activity of methane oxidizing bacteria in permafrost soils from the Lena Delta, Siberia. Environ. Microbiol., 9(1), 107-117.

Liebner, S., K. Rublack, T. Stuehrmann and D. Wagner. 2009. Diversity of aerobic methanotrophic bacteria in a permafrost active layer soil of the Lena Delta, Siberia. Microbial Ecol., 57(1), 25-35.

McDonald, I.R. and J.C. Murrell. 1997. The particulate methane monooxygenase gene $p m o A$ and its use as a functional gene probe for methanotrophs. FEMS Microbiol. Lett., 156(2), 205-210.

McDonald, I.R., G.H. Hall, R.W. Pickup and J.C. Murrell. 1996. Methane oxidation potential and preliminary analysis of methanotrophs in blanket bog peat using molecular ecology techniques. FEMS Microbiol. Ecol., 21(3), 197-211.

Martineau, C., L.G. Whyte and C.W. Greer. 2010. Stable isotope probing analysis of the diversity and activity of methanotrophic bacteria in soils from the Canadian High Arctic. Appl. Environ. Microbiol., 76(17), 5773-5784.

Mastepanov, M. and 6 others. 2008. Large tundra methane burst during onset of freezing. Nature, 456(7222), 628-630.

Mernild, S.H., D.L. Kane, B.U. Hansen, B.H. Jakobsen, B. Hasholt and N.T. Knudsen. 2008. Climate, glacier mass balance and runoff (1993-2005) for the Mittivakkat Glacier catchment, Ammassalik Island, SE Greenland, and in a long term perspective (1898-1993). Hydrol. Res., 39(4), 239-256.

Mosier, A., D. Schimel, D. Valentine, K. Bronson and W. Parton. 1991. Methane and nitrous oxide fluxes in native, fertilized and cultivated grasslands. Nature, 350(6316), 330-332.

Muyzer, G. and K. Smalla. 1998. Application of denaturing gradient gel electrophoresis (DGGE) and temperature gradient gel 
electrophoresis (TGGE) in microbial ecology. A. Van Leeuwenhoek J. Microbiol., 73(1), 127-141.

Nemergut, D.R. and 6 others. 2007. Microbial community succession in an unvegetated, recently deglaciated soil. Microbial Ecol., 53(1), 110-122.

Nørnberg, P. and K. Dalsgaard. 2005. Methods of soil and water analyses. Aarhus, University of Aarhus. Department of Earth Sciences. (Aarhus Geocompendia 3.)

Priemé, A. and S. Christensen. 1997. Seasonal and spatial variation of methane oxidation in a Danish spruce forest. Soil Biol. Biochem., 29(8), 1165-1172.

Radajewski, S. and 7 others. 2002. Identification of active methylotroph populations in an acidic forest soil by stableisotope probing. Microbiology, 148(8), 2331-2342.

Ricke, P., M. Kube, S. Nakagawa, C. Erkel, R. Reinhardt and W. Liesack. 2005. First genome data from uncultured upland soil cluster alpha methanotrophs provide further evidence for a close phylogenetic relationship to Methylocapsa acidiphila B2 and for high-affinity methanotrophy involving particulate methane monooxygenase. Appl. Environ. Microbiol., 71(11), 7472-7482.

Schmidt, S.K. and 10 others. 2008. The earliest stages of ecosystem succession in high-elevation (5000 metres above sea level), recently deglaciated soils. Proc. $R$. Soc. London, Ser. B, 275(1653), 2793-2802.

Sigler, W.V. and J. Zeyer. 2002. Microbial diversity and activity along the forefields of two receding glaciers. Microbial Ecol., 43(4), 397-407

Sigler, W.V., S. Crivii and J. Zeyer. 2002. Bacterial succession in glacial forefield soils characterized by community structure, activity and opportunistic growth dynamics. Microbial Ecol., 44(4), 306-316.

Smith, K.A. and 16 others. 2002. Oxidation of atmospheric methane in Northern European soils, comparison with other ecosystems, and uncertainties in the global terrestrial sink. Global Change Biol., 6(7), 791-803.
Strauss, S.L., C.T. Ruhland and T.A. Day. 2009. Trends in soil characteristics along a recently deglaciated foreland on Anvers Island, Antarctic Peninsula. Polar Biol., 32(12), 1779-1788.

Trevors, J.T., P.G. Kevan and L. Tam. 2010. Microbial diversity across a Canadian sub-Arctic, isostatically rebounding, soil transect. Polar Sci., 4(1), 81-91.

Trotsenko, Y.A. and J.C. Murrell. 2008. Metabolic aspects of aerobic obligate methanotrophy. Adv. Appl. Microbiol., 63, 183-229.

Tscherko, D., J. Rustemeier, A. Richter, W. Wanek and E. Kandeler. 2003. Functional diversity of the soil microflora in primary succession across two glacier forelands in the Central Alps. Eur. J. Soil Sci., 54(4), 685-696.

Vallaeys, T. and 6 others. 1996. Evaluation of denaturing gradient gel electrophoresis in the detection of $16 \mathrm{~S}$ rDNA sequence variation in rhizobia and methanotrophs. FEMS Microbiol. Ecol., 24(3), 279-285.

Von Fischer, J.C., G. Butters, P.C. Duchateau, R.J. Thelwell and R. Siller. 2009. In situ measures of methanotroph activity in upland soils: a reaction-diffusion model and field observation of water stress. J. Geophys. Res., 114(G1), G01015. (10.1029/ 2008JG000731.)

Wadham, J.L., M. Tranter, S. Tulaczyk and M. Sharp. 2008. Subglacial methanogenesis: a potential climatic amplifier? Global Biogeochem. Cycles, 22(GB2), GB2021. (10.1029/2007GB002951.)

Whalen, S.C. and W.S. Reeburgh. 1990. Consumption of atmospheric methane by tundra soils. Nature, 346(6280), 160-162.

Yavitt, J.B., J.A. Simmons and T.J. Fahey. 1993. Methane fluxes in a northern hardwood forest ecosystem in relation to acid precipitation. Chemosphere, 26(1-4), 721-730.

Yde, J.C. and N.T. Knudsen. 2007. 20th-century glacier fluctuations on Disko Island (Qeqertarsuaq), Greenland. Ann. Glaciol., 46, 209-214.

Yoshitake, S., M. Uchida, H. Koizumi and T. Nakatsubo. 2007. Carbon and nitrogen limitation of soil microbial respiration in a High Arctic successional glacier foreland near Ny-Ålesund, Svalbard. Polar Res., 26(1), 22-30. 